\title{
ANALISIS TAHAPAN MENULIS DAN STIMULASI ANAK KELOMPOK B-1 DI TK ISLAM ASSAADAH LIMO DEPOK
}

\author{
Ana Widyastuti \\ Universitas Indraprasta PGRI \\ Email: anawidyastuti35@gmail.com
}

Artikel Diterima: 01 Juni 2017 Proses Review Artikel: 24 Agustus 2017

Artikel Diterbitkan: 30 September 2017

\begin{abstract}
ABSTRAK
Anak usia dini mulai mengenal diri lingkungannya merupakan masa keemasan atau yang biasa disebut dengan "golden age". Masa usia dini merupakan masa proses berlangsungnya pendidikan, yakni sejak usia anak dalam kandungan , masa bayi hingga anak berusia delapan tahun. Masa inilah masa dimana lingkungan memberikan rangsangan positif. Lingkungan keluarga maupun lingkungan sekolah sangat berperan penting. Stimulasi-stimulasi yang positif sangat diperlukan agar anak usia dini memiliki pertumbuhan dan perkembangan yang optimal. Aspek-aspek yang perlu distimulasi sangat banyak. Salah satu diantaranya adalah kemampuan berbahasa.. Banyaknya keluhan dari guru yang siswanya berada pada tahap perkembangan menulis tidak seperti yang diharapkan. Artinya, tahapan perkembangan menulis anak belum dapat berkembang dengan optimal..Tujuan dari penelitian ini ialahmengobservasi sejauhmana proses tahapan menulis pada anak TK khususnya kelompok B-1 yang berusia 5- 6 tahun, menganalisis sesuai tahapan perkembangan menulis pada anak serta stimulasitepat yang dilakukan guru guna mengoptimalkan kemampuan menulis anak. Metode yang digunakan deskriptif kualitatif. Penelitian deskriptif kualitatif berupaya untuk mengungkapkan gejala permasalahan sesuaidengan konteksnyadenganmemanfaatkandiri peneliti sebagai instrumen kunci.Berdasarkan pengetahuan, kepekaan, kecermatan, dan kekritisannya, peneliti mencari, menggali, menelaah, dan menyimpulkan hal-hal yang berkaitan dengan permasalahan penelitian. Subjek dalam penelitian ini adalah hasil karya anak berupa tahapan perkembangan menulis anak kelompok B berjumlah 15. Hasil peneltian yaitu pada tahap perkembangan menulis dari 15 anak, kurang $=2$ anak, cukup $=8$ anak, baik $=4$ anak, sangat baik=1 anak, Stimulasi diberikan sesuai dengan hasil tersebut.
\end{abstract}

Kata Kunci: tahapan menulis, stimulasi, kelompok B

\section{PENDAHULUAN}

Pendidikan Anak Usia Dini (PAUD) merupakan pendidikan yang paling fundamental karena perkembangan anak di masa selanjutnya akan sangat ditentukan oleh berbagai stimulasi bermakna yang diberikan sejak usia dini. Awal kehidupan anak 
merupakan masa yang paling tepat dalam memberikan dorongan atau upaya pengembangan agaranak berkembang secara optimal.

Undang-Undang Nomor 20 Tahun 2003 tentang Sistem Pendidikan Nasional Bab 1 Pasal 1 butir 14 menyatakan bahwa PAUD merupakan suatu upaya pembinaan yang ditujukan kepada anak sejak lahir sampai dengan usia 6 tahun yang dilakukan melalui rangsangan pendidikan untuk membantu pertumbuhan dan perkembnagan jasamai dan rohani agar anak memiliki kesiapan belajar dalam memasuki pendidikan lebih lanjut. (Kemendikbud: 2015)

Anak usia dini mulai mengenal diri lingkungannya merupakan masa keemasan atau yang biasa disebut dengan "golden age". Masa usia dini merupakan masa proses berlangsungnya pendidikan, yakni sejak usia anak dalam kandungan , masa bayi hingga anak berusia delapan tahun. Masa inilah masa dimana lingkungan memberikan rangsangan positif.Lingkungan keluarga maupun lingkungan sekolah sangat berperan penting. Stimulasistimulasi yang positif sangat diperlukan agar anak usia dini memiliki pertumbuhan dan perkembangan yang optimal. Aspek-aspek yang perlu distimulasi sangat banyak. Salah satu diantaranya adalah kemampuan berbahasa..

Pengembangan keterampilan berbahasa pada anak usia dini mencakup empat aspek yaitu: berbicara, menyimak, membaca dan menulis. Keterampilan berbicara dan menulis merupakan keterampilan yang bersifat produktif karena anak dituntut untuk menghasilkan bahasa.Banyaknya keluhan dari guru yang siswanya berada pada tahap perkembangan menulis tidak seperti yang diharapkan. Artinya, tahapan perkembangan menulis anak belum dapat berkembang dengan optimal.

Berdasarkan pemaparan di atas, penulis mencoba untuk mengobservasi sejauhmana proses tahapan menulis pada anak TK khususnya kelompok B-1 yang berusia 5- 6 tahun, kemudian menganalisis sesuai tahapan perkembangan menulis pada anak serta stimulasi apa saja yang dilakukan guru guna mengoptimalkan kemampuan menulis anak. Peneliti menganalisis coretan atau gambar siswa-siswa kelompok B-1 dan mengklasifikasikan tahapan menulis.Kemudian memberikan stimulasi sesuai dengan ranah tahapan menulis siswa. 
Menulis adalah kegiatan berbahasa yang bersifat produktif.Seorang penulis menyampaikan gagasan, perasaan informasi dalam bentuk tulisan. Menulis adalah menurunkan atau melukiskan lambing-lambang grafis yang menggambarkan suatu bahasa yang dipahami oleh seseorang sehingga orang lain dapat membaca lambang-lambang grafis tersebut (Bryne dalam Kundharu Saddhono: 1993).

Kemampuan menulis pada anak usia 4-6 tahun atau usia taman kanak- kanak meliputi kemampuan dan keterampilan memegang alat-alat tulis-menulis, membuka dan menutup buku, menggunakan alat penghapus ketika harus menghapus gambar atau tulisan, cara duduk yang benar, kemampuan membuat coretan, menggambar garis lurus, garis miring, garis lengkung, segitiga, segi empat, danlingkaran, (Montessori dalam Susanto).

Menurut Sarahaswati, Hasti dan sadiah Kusumahwati (2016), Perkembangan berbicara dan menulis merupakan proses menggunkan bahasa ekspresif dalam membentuk arti. Kajian tentang perkembangan menulis pada anak berkaiatan dengan suatu proses yang dilakukan anak sehingga menghasilkan bentik tulisan.

Menulis dapat di definisikan sebagai suatu kegiatan penyampaian pesan (komunikasi) dengan menggunakan bahasa tulis sebagai alat atau medianya.Pesan adalah isi atau muatan yang terkandung dalam suatu tulisan.Tulisan merupakan sebuah symbol atau lambang bahasa yang dapat dilihat dan disepakati pemakainya. Dengan demikian, dalam komunikasi tulis paling tidak terdapat empat unsur yang terlihat: penulis sebagai penyampai pesan (penulis), pesan atau isi tulisan, saluran atau media berupa tulisan, dan pembaca sebagai penerima pesan. Artikel, esai, laporan, resensi, karya sastra, buku, komik, dan cerita adalah contoh bentuk dan produk bahasa tulis yang akrab dengan kehidupan kita. Tulisan-tulisan itu menyajikan secara runtut dan menarik, ide, gagasan, dan perasaan penulisnya.(Suparno \& M. Yunus)

\section{Pengertian Menulis Permulaan.}

Kegiatan menulis merupakan kegiatan yang dilakukan oleh seseorang untuk menyampaikan ekspresi diatas kertas yang memiliki makna dan pesan tersendiri. Hal ini sesuai dengan pendapat Lado (dalam Tarigan: 2008), menulis adalah menurunkan atau melukiskan lambang-lambang grafik yang menggambarkan suatu bahasa yang dipahami seseorang sehingga orang lain dapat membaca lambang-lambang grafik ini, apabila mereka 
memahami bahasa dan grafik tadi. Menulis juga merupakan suatu representasi bagian dari kesatuan-kesatuan ekspresi bahasa.

Ismayani (2010) mengatakan menulis dini adalah berawal dengan anak mengenal alat tulis, seperti crayon, pensil dan bolpoint. Selanjutnya anak akan menggunakannya untuk mencoret di manapun anak menyukainya. Proses mencoret itulah anak belajar menulis, belajar menggenggam, dan belajar berimajinasi. Pada anak usia dini menulis dini dapat juga disebut sebagai menulis permulaan. Sehingga kegiatan menulis pada anak usia dini merupakan kegiatan yang menyenangkan, yang mana menulis di usia dini dapat membantu anak untuk berkreasi. Menulis yakni: Perkembangan kemampua menulis anak TK diawali pertama kali anak mampu memegang krayon atau pensil. Menurut Poerwadarminta (1982), menulis memilikibatasan sebagai berikut: (1) membuat huruf, angka dan lainnya dengan pena, kapusr dan sebagainya;(2) mengekspresikan pikiran dan perasaan seperti mengrang,membuat surat dan lainnya dengan tulisan.

\section{Tahapan Perkembangan Menulis Anak}

Kemendikbud (Brewer:2013) memaparkan bahwa tahapan perkembangan menulis anak usia dini adalah sebagai berikut:

a. Scribble stage (tahap mencoret atau membuat goresan). Pada tahap ini anak mulai membuat tanda-tanda dengan menggunakan alat-alat tulisan. Anak mulai belajar bahasa tulisan. Biasanya dilakukan di dinding, kertas, atau apa saja yang dianggapnya dapat ditulis. Orang tua dan guru pada tahap mencoret dapat menjadi model dan menyediakan bahan untuk menulis seperti cat, buku, kertas dan krayon.

b. Linear repetitive stage (tahap pengulangan secara linier). Tahap selanjutnya dalam perkembnagan menulis adalah tahap pengulangan secara linear. Pada tahap ini, anak menelusuri bentuk tulisan yang horizontal. Tulisan yang dihasilkan anak seperti membuat gambar rumput. Orangtua dan guru memberi kegiatan yang berkaitan dengan tulisan, misalnya bermain peran di restoran, dimana seorang pramusaji menuliskan menu yang akan dipesan oleh pelanggan, atau seorang dokter yang akan menulis resep obat. Kegiatan tersebut akan membantu anak untuk menyenangi menulis. Biasanya anak akan ingat kata apa saja yang ditulis walaupun bentuk tulisannya seperti rumput. 
c. Random letter stage (tahap menulis secara random). Pada tahap ini, anak belajar tentang berbagai bentuk yang dapat diterima sebagai suatu tulisan walupun huruf yang muncul masih acak. Kegiatan ini membantu anak untuk menuangkan ide pada gambar menjadi tulisan walaupun kata yang muncul tidak utuh (hurufnya acak), contoh: anak ingin menulis kata " aku pergi ke taman safari” tetapi yang muncul "aku pgi k tmn sfri".

d. Letter name writing or Phonetic writing stage (tahap menulis tulisan nama). Pada tahap ini, anak mulai menyusun hubungan abtara tulisan dan bunyi. Permulaan tahap ini sering digambarkan sebagai menulis tulisan nama karena anak-anak menulis tulisan nama dan bunyi secara bersamaan. Sebagai contoh, anak menulis kata "dua" dengan "duwa”, "pergi” dengan "pegi", "sekolah" dengan "skola". Pada tahap ini anak menulis sesuai dengan apa yang ia dengar.

Jadi tahapan perkembangan menulis anak itu sangat penting karena merupakan dasar fundamental anak dalam proses menulis sehingga kamampuan menulisnya dapat optimal.

\section{Manfaat Menulis}

Beberapa manfaat yang dapat di petik dari menulis dalam Suparno dan Yunus (2002) di antaranya: Peningkatan kecerdasan; Mengembangkan daya inisiatif dan kreatifitas; Menumbuhkan keberanian; dan Mendorong kemauan dan kemampuan mengumpulkan informasi.

Sering kali terjadi anak-anak diminta untuk menggunakan pensil, padahal mereka belum siap untuk menggunakan alat tersebut. Kemampuan menulis selain memerlukan otot kecil pada jari, tangan dan pergelangan juga perlunya berfikir. Hal ini dapat menyebabkan anak tidak mau menulis, karena anak belum mampu untuk melakukan kegiatan tersebut, dan merasa tidak tahu bagaimana harus menulis akibatnya anak jadi tidak suka menulis. Ketidaksukaan tak lepas dari pengaruh orang tua dan guru yang kurang memotivasi dan merangsang minat anak untuk melakukan kegiatan menulis. Smith (Suparno dan Yunus, M 2002) mengatakan bahwa "Pengalaman belajar menulis yang dialami siswa di sekolah tidak terlepas dari gurunya sendiri". Dengan demikian guru harus bisa menstimulus dan memotivasi anak untuk melakukan kegiatan menulis agar kegiatan tersebut disukai oleh anak. Oleh sebab itu guru harus bisa menciptakan kegiatan yang asyik dan menyenangkan. Dalam kehidupan 
modern ini jelas bahwa keterampilan menulis sangat dibutuhkan, sehingga kelak anak diharapkan mampu menguasai kemampuan menulis pada saat melanjutkan kesekolah dasar.

\section{Stimulasi Menulis}

\section{a. Pengertian Stimulasi}

Dalam Kamus Besar Bahasa Indonesia (KBBI) (Depdiknas:2014) stimulasi adalah dorongan, rangsangan. Menurut Kemendikbud (2015)

"Stimulasi adalah pemberian rangsangan pendidikan yang diberikan untuk mencapai kompetensi sikap, pengetahuan, dan keterampilan bagi anak usi dari lahir sampai dengan 6 tahun agar dapat tumbuh dan berkembang secara optimal.Stimulasi bahasa tulis berarti merangsang anak untuk mngenali, memahami, dan menggunakan symbol tertulis dari bahasa atau langue-nya untuk berkomunkasi seauai tahap perkembangannya. Rangsang diberikan dalam berbagai bentuk, mulai dari permainan bentuk hingga produksi."

\section{b. Tujuan Stimulasi pada Anak}

Tadkirotun Musfiroh (2008) mengemukakan bahwa tujuan stimulasi bahasa tulis untuk anak adalah: a) Menumbuhkan kesadaran fungsional,yakni berkomunikasi dapat dilakukan dengan tulisan dan bahwa tulisan dibuat seseorang untuk berkomunikasi, b) Menunjukkan wujud nyata tulisan yang digunakan seseorang untuk menyampaikan ide dalam berbagai fungsi, c) Menumbuhkan kesadaran grafemis dan grafofonemik anak, d) Menumbuhkan budaya dan minat baca anak, e) Memberikan pengalaman langsung pada anak untuk terlibat dalam bahasa tubuh yang riil, f) Menumbuhkan minat menulis pada anak sebagai wujud komunikasi sekunder sesuai kebutuhan anak

\section{c. Manfaat Stimulasi}

Apabila dilakukan dengan benar, stimulasi bahasa tulis untuk anak usia dinimemiliki banyak manfaat. Sebaliknya apbila dilakukan secara tidak tepat, stimulasi bahasa tulis akan mengandung banyak resiko.adapun manfaat stimulasi bahasa tulis yang benar pda anak yaitu: a) Mendekatkan pada anak pada bahasa tulis yang otentik. Dengan demikian anak telah didorong untuk mencapai tahap fungsional berbahasa tulis, b) Melandasi anak agar cakap berbahasa tulis sesuai tahap perkembangannya. Dengan demikian, anak akan terhindar dari beban belajar yang berlebihan, c) Memberikan wadah bagi anak untuk belajar mengekspresikan ide, kemauan, dan perasaannya secara bebas tanpa beban instruksi. Dengan 
demikian, anak belajar secara langsung bagaimana mengontrol bentuk danisi pesan secara tertulis, d) Memberikan bantuan yang tepat waktu dan tepat sasaran,serta mengikis pembelajaran sentral guru menuju ke pembelajaran sentral anak. Dengan demikian, belajar benar-benar didasarkan pada kebutuhan anak.(Tadkirotun Musfiroh (2008)

\title{
d. Prinsip Stimulasi Bahasa Tulis pada Anak
}

Tadkirotun Musfiroh (2008: 12-16) memaparkan bahwa:

\begin{abstract}
"Stimulasi yang paling baik diberikan pada masa anak-anak adalah melalui bermain., karena bermain adalah sumber perkembangan dan membentuk zone of proximal development (ZPD) (Vygotsky, 1967). Dalam bermain terjadi proses representasi simbolik, eksplorasi, eksperimentasi, penguasaan (mastery), penemuan (invention), ekspresi artistik, .menemukan manfaat (rewarding) dan cara yang tepat (apprioriate) untuk berinteraksi dengan orang lain (Bronson, 1999). Proses belajar, menurut pandangan kontruktivistik harus menekankan keterlibatan anak. Menurut pandangan ini, proses belajar haruslan menyenangkan bagi anak dan emmungkinkan berinteraksi secara aktif dengan lingkungannnya. Bermain merupakan media sekaligus cara terbaik anak untuk belajar. Dengan bermain itulah anak belajar melalui proses berbuat dan meyentuh langsung objek-objek nyata.anak tidak belajar banyak melalui interpretasi stimulus verbal (kata-kata) dari orang yang lebih dewasa."
\end{abstract}

Stimulus bahasa tulis melalui bermain (Cox, 1999) harus didasarkan pada hal-hal berikut ini: (a) Imersi, Anak-anak benar-benar tenggelam dalam lungkungan bahasa yang mereka pelajari. Oleh karena itu, sediakan lingkungan yang kaya akan bahan cetakan, alat peraga, buku-buku, tanda-tanda, tabel-tabel daan label-label. Anak-anak akan membaca keraskeras apa yang ada di sekelilingnya, (b) Demonstrasi, Agar suntuk atau tenggelam dalam proses belajar bahasa, anak-anak membutuhkan demonstrasi dari kegiatan orang di sekitarnya. Oleh karena itu, orang tua dan guru, sebaiknya menjadi model menulis, membaca dan berbicara bagi anak, (c) Keterlibatan, Proses belajar terjadi ketika anak secaraaktif terhadap apa yang mereka lakukan. Hal ini merefleksikan suatu perspektifkonstruktif dari belajar dan mengajar. Anak-anak akan memilih sendiri apa yang mereka ingin baca dan kemudian mendramatisasikannya, (d) Ekspektasi, Guru mengharapkan bahwa ia dapat mengajar dan anak-anak dapat belajar. Anak-anak harus memperoleh cukup kesempatan setiap hari untuk membaca dan menulis.guru harus selalu mendorong mereka untuk menjadi pembacadan penulis, (e) Tanggung jawab, Anak-anak perlu belajar bertanggungjawab terhadap topik yang dipilih dan menemukan kesempatan untuk melakukannya.guru perlu menyediakan waktu dan 
tempat khusus bagi mereka, (f) Aproksimasi, Anak-anak mengira-ira bentuk dan penggunaan bahasa.Orang tua dan guru mendorong anak untuk melakukan.Tipe dukungan inipenting daripada kesalahan yang dibust. Anak-anak akan membuat prakiraa yang semakin rumit tentang penggunaan bahasa, tergantung pada tingkat perkembangan mereka, (g) Penggunaan, Apabila anak-anak belajar bahasa lisan dengan menyimak dan berbicara, mereka akan belajar bahasa tulis dengan belajar membaca dan menulis, serta menerapkan perkembangan pemahaman dan keterampilan mereka tentang bagaimana bahasa cetak berperan di kelas. Anak memiliki pengalaman dengan huruf-huruf.membaca dan menulis diintegrasikan ke dalam kegiatan sehari-hari dan dihubungkan dengan pengalaman anak.Anak belajar bagaimana menggunakan bahasa dalam situasi yang otentik dan bermakna, (h) Respon, Sebagaimana input dan pajanan dalam bahasa lisan, respon dalam bahasa tulis pun berperan bagi anak. Setiap pertanyaan yang diajukan merupakan materi yang bermakna dan termanfaatkan oleh anak dalam proses hipotesis dan pengujiannya. Pertanyaan yang berkaitan dengan nama huruf, lafal, car abaca merupakan pertanyaan yang memerlukan respon segera. (Tadkirotun Musfiroh (2008)

\section{e. Stimulasi Bahasa Tulis}

Menurut Tadkirotun Musfiroh (2008) stimulasi bahasa tulis ada dua yaitu sebagai berikut: 1) Stimulasi Bahasa Tulis Reseptif: Stimulasi tterbaik adalah menstimulasi anak agar mereka tertarik membaca, senang terhadap tulisan dan kesadaran fonem dan leksikal. Menurut Jalongo dan kawan-kawan, buku-buku yang penuh gambardengan sedikit tulisan justru efektif untuk mendorong anak senng membaca (Jalongo, et.al 2002). Menurut beberpa ahli, kemunculan bahasa tulis pada anakdapat dirangsng melaluiberbagai macam kegiatan, antara lain melalui rekonstruksi cerita dan buku bergambar. Menurut penelitian Kraayenood \& Paris (1996),kegiatan mengkonstrusi cerita dari buku bergambar daptmembangkitkan bahasa tulisanak, terutama karena berkaitan dengan aktivitas memaknai dan mengkonstruksi pemahaman.Kegiatan ini dapat dipergunakan untuk mengukur kemampuan anak mendekodingmakna teks. 2) Stimulasi Bahasa Tulis Produktif: Stimulasi bahasa tulis produktif dilakukan dengan memperhatikan perkembangan menulis anak.Dengan demikian, pemberian stimulasidapat diberikan secara tepat. Melalui observasinya terhadap anak-anak, 
Mary Clay (Brewer, 1995), menunjukkan bahwa perkembangan menulis anak mengikuti prinsip-prinsip Anak-anak belajar bahwa objek atau peristiwa dapat dilambangkan dengan simbol.Anak kemudianbelajar bahwa huruf meupakan symbol yang arbitrer dan tidak berkaitan dengan referennya.

a) Prinsip mengkopi, Anak seringkali mencontoh model-model yang ada di sekitarnya, seperti logo, dan nama. Anak-anak senang melihat namanya tercetak dalam wujud tulisan.

b) Prinsip Fleksibel, Anak-anak menemukan bahwa ternyata hurufmemiliki erbagai variasi. Anak-anak belajar mengkonstruksi dan mengenalibentuk-bentuk huruf yang sama.

c) Prinsip Inventori, Anak-anak sering menginventarisasikan "tulisan"mereka secara sistematis. Mereka membuat daftar huruf yang mereka tahu, atau kata-kata yang dapat mereka tulis. Guru kadang-kadang meminta anak-anak menuliskan kata atau huruf yang mereka tahu, dan anak pun melengkapai koleksi mereka seketika itu

d) Prinsip Keberulangan, Anak mengulaing apa yang mereka "tulis" walaupun dalam bentuk yang berbeda. Satu huruf atau kata kadang diulang beberapa kali dalam sekali tulis.

e) Prinsip Membangkitkan, Anak-anak menggunakan beberapa elemen menulis yang sama dan eberapa kaidah dan mengkombinasikannya untuk membentuk kalimat yang baru. Hal ini merupakan dasar untuk mengembangkan bahasa lisan karena anak-anak tidak sellu pernah mendengar setiap kalimat yang ingin mereka produksi (Tadkirotun Musfiroh 2008)

\section{METODOLOGI}

Penelitian ini dikategorikan sebagai penelitian deskriptif kualitatif. Penelitian deskriptif kualitatif menerapkan langkah-langkah penelitian yang menghasilkan data deskriptif berupa kata-kata tertulis. Penelitian deskriptif kualitatif berupaya untuk mengungkapkan gejala permasalahan sesuai dengan konteksnya dengan memanfaatkan diri peneliti sebagai instrumen kunci. Berdasarkan pengetahuan, kepekaan, kecermatan, dan kekritisannya, peneliti mencari, menggali, menelaah, dan menyimpulkan hal-hal yang berkaitan dengan permasalahan penelitian.

Penelitian ini adalah penelitian kajian pustaka, sehingga pengkajiannya tidak dibatasi oleh lokasi tertentu. Namun, dalam hal ini, penelitian dilakukan di Depok. Penelitian mulai dilakukan pada bulan Mei 2017 sampai dengan bulan September 2017. 
Subjek penelitian dalam penelitian ini adalah hasil karya anak berupa tahapan perkembangan menulis anak kelompok B berjumlah 15. Kriteria pemilihan sampel ini adalah siswa kelompok B TK Islam Assaadah. Hasil pengembangan yang berupa tindak lanjut dengan stimulasi ini akan diuji cobakan dalam pembelajaran di Kelompok B TK Islam Assaadah Limo Depok dan hasilnya akan dianalisis secara deskriptif.

\section{Populasi}

Populasi adalah keseluruhan objek penelitian (Suharsimi Arikunto 2006:130). Menurut Sugiyono (2012), populasi adalah wilayah generalisasi yang terdiri atas obyek yang mempunyai kualitas dan karakteristik tertentu yang ditetapkan oleh peneliti untuk dipelajari dan kemudian ditarik kesimpulannya. Populasi dalam penelitian ini adalah murid TK (Taman Kanak-Kanak) Kelompok B-1 di TK Islam Assaadah kecamatan Limo Depok.

\section{Sampel}

Suharsimi Arikunto (2006) mengatakan bahwa sampel adalah sebagian atau wakil dari jumlah populasi yang diteliti.Sugiyono (2012), sampel adalah bagian dari jumlah dan karakteristik yang dimiliki oleh populasi tersebut. Jadi, apa yang dipelajari dalam sampel itu kesimpulannya akan dapat digeneralisasikan untuk populasi. Untuk itu sampel yang diambil dari populasi harus representative (mewakili). Sampel dalam penelitian ini adalah 15 orang anak Kelompok B TK Islam Assaadah kecamatan Limo Depok.

\section{Metode Pengumpulan Data}

Menurut Arikunto (2006) teknik pengumpulan data adalah cara yang digunakan oleh peneliti untuk memperoleh data yang dibutuhkan. Dalam penggunaan tenik pengumpulan data, peneliti memerlukan instrumen yaitu alat bantu agar pengerjaan pengumpulan data menjadi lebih mudah. Data yang digunakan adalah data primer.Pengumpulan data dimaksudkan untuk memperoleh data yang sesuai serta akurat dengan tujuan yang ingin dicapai. Teknik pengumpulandatadengan instrumenberupaobservasi, tes, dan dokumentasi.Berikut ini adalah penjabaran metode tersebut.

Observasi, Burhan Nurgiyantoro (2012) mengemukakan bahwa observasi (pengamatan) merupakan cara untuk mendapatkan informasi dengan cara mengamati objek secara cermat dan terencana. Pengamatan dilakukan terhadap objek secara langsung, cermat, dan sistematis dengan mendasar pada rambu-rambu tertentu.Biasanya kegiatan pengamatan 
disertai dengan pencatatan terhadap sesuatu yang diamati. Peneliti melakukan observasi dengan melakukan pengamatan langsung kegiatan pembelajaran menulis di kelompok B-1 TK Islam Assaadah. Selain melakukan pengamatan, peneliti juga melakukan pencatatan menggunakan hasil tahapan menulis siswa melalui lembar observasi. Melalui observasi, peneliti akan mengetahui kendala-kendala yang dihadapi oleh siswa dalam proses tahapan menulis.

Tes, Suharsimi Arikunto (2006) mengemukakan bahwa tes adalah serentetan pertanyaan atau latihan serta alat lain yang digunakan untuk mengukur keterampilan, pengetahuan inteligensi, kemampuan atau bakat yang dimiliki oleh individu atau kelompok. Kegiatan pembelajaran tahapan menulis siswa dan stimulasinya akan diberikan kepada siswa kelompok B-1 di akhir setiap siklus. Tes yang digunakan oleh peneliti adalah untuk menganalisis tahapan menulis siswa dan stimulasinya melalui alat permainan edukatif pada siswa kelompok B-1 TK Islam Assaadah di kecamatan Limo Depok.

Dokumentasi, Suharsimi Arikunto (2006) mengemukakan bahwa dokumentasi berasal dari kata dokumen, yang artinya barang-barang tertulis.Dalam mendokumentasikan, peneliti menyelidiki benda-benda tertulis seperti buku-buku, majalah, dokumen, peraturanperaturan, notulen rapat, catatan harian, dan sebagainya. Peneliti akan mengambil data dokumentasi berupa foto saat proses pembelajaran tahapan menulis cerita siswa, hasil tahapan menulis dan stimulasi kegiatan pembelajaran melalui bermain.

\section{Instrumen Penelitian}

Arikunto (2006) mengemukakan bahwa instrumen penelitian adalah alat yang digunakan oleh peneliti dalam mengumpulkan data agar pekerjaan lebih mudah dan hasilnya lebih baik.Alat yang digunakan oleh peneliti sebagai alat pengumpulan data adalah lembar observasi dan tes hasil belajar.

Tabel 1 Hasil karya berupa Tahapan Menulis Siswa Kelompok B-1

\begin{tabular}{|l|l|l|l|l|l|l|l|}
\hline No & \multirow{2}{*}{$\begin{array}{c}\text { Nama } \\
\text { Anak }\end{array}$} & \multicolumn{4}{|c|}{ Tahapan Perkembangan Menulis } & Penilaian & Penilaia \\
Rata-rata & Minggu \\
ke-1 & & $\begin{array}{c}\text { Minggu } \\
\text { ke-2 }\end{array}$ & $\begin{array}{c}\text { Minggu } \\
\text { ke-3 }\end{array}$ & $\begin{array}{c}\text { Minggu } \\
\text { ke-4 }\end{array}$ & \\
\hline 1. & Fian & Tahap 2 & Tahap 2 & Tahap 3 & Tahap 2 & 2 & Cukup \\
\hline 2. & Azizah & Tahap 2 & Tahap 3 & Tahap 3 & Tahap 2 & 3 & Baik \\
\hline 3. & Annisa & Tahap 2 & Tahap 3 & Tahap 4 & Tahap 3 & 3 & Baik \\
\hline 4. & Dimas & Tahap 3 & Tahap 4 & Tahap 4 & Tahap 3 & 4 & Sangat \\
\hline
\end{tabular}




\begin{tabular}{|l|l|l|l|l|l|l|l|}
\hline & & & & & & & baik \\
\hline 5. & Inu & Tahap 2 & Tahap 3 & Tahap 2 & Tahap 2 & 2 & Cukup \\
\hline 6. & Mayda & Tahap 1 & Tahap 2 & Tahap 2 & Tahap 3 & 2 & Cukup \\
\hline 7. & Fadly & Tahap 1 & Tahap 2 & Tahap 3 & Tahap 2 & 2 & Cukup \\
\hline 8. & Fajar & Tahap 3 & Tahap 2 & Tahap 2 & Tahap 3 & 3 & Baik \\
\hline 9. & Juan & Tahap 2 & Tahap 2 & Tahap 2 & Tahap 2 & 2 & Cukup \\
\hline 10. & Rifa & Tahap 1 & Tahap 1 & Tahap 2 & Tahap 1 & 1 & Kurang \\
\hline 11. & Nizam & Tahap 1 & Tahap 1 & Tahap 2 & Tahap 1 & 1 & Kurang \\
\hline 12. & Nur & Tahap 2 & Tahap 1 & Tahap 2 & Tahap 1 & 2 & Cukup \\
\hline 13 & Syifa & Tahap 2 & Tahap 1 & Tahap 2 & Tahap 2 & 2 & Cukup \\
\hline 14. & Aldi & Tahap 1 & Tahap 2 & Tahap 3 & Tahap 3 & 3 & Baik \\
\hline 15. & Ibnu & Tahap 3 & Tahap 2 & Tahap 2 & Tahap 2 & 2 & Cukup \\
& & & & & & \\
\hline
\end{tabular}

\section{Tes Hasil Belajar}

Berikut adalah kisi-kisi pedoman Tes Hasil Belajar yang akan digunakan untuk mengukur keterampilan Tahapan Perkembangan menulis Anak kelompok B-1 TK Islam Assaadah Limo Depok

Tabel 2 Hasil Belajar Tahapan Perkembangan Menulis Anak Kelompok B-1

\begin{tabular}{|c|c|}
\hline Nilai/ Skor & Keterangan \\
\hline 4 & Sangat Baik \\
\hline 3 & Baik \\
\hline 2 & Cukup \\
\hline 1 & Kurang \\
\hline
\end{tabular}

\section{Teknik Analisis Data}

Teknik analisis data yang digunakan yaitu teknik kuantitatif dan kualitatif yaitu dengan mencari nilai rata-rata tahapan perkembangan menulis anak. Data yang diperoleh dalam penelitian ini adalah nilai proses tahapan perkembangan menulis anak yang dibuat oleh guru. Setelah dievaluasi megenai pembuatan cerita dan kemampuan dwibahasa para guru, dilakukan analisa data sesuai dengan kriterian penilaian menurut Suharsimi Arikunto (2006) adalah sebagai berikut. 
Tabel 3 Kriteria Keberhasilan Tahapan Menulis Cerita Siswa

\begin{tabular}{|l|c|l|}
\hline Tahapan Menulis & Skor & \multicolumn{1}{c|}{ Stimulasi } \\
\hline Scribble stage & 1 & $\begin{array}{l}\text { Orang tua dan guru pada tahap mencoret dapat menjadi } \\
\text { model dan menyediakan bahan untuk menulis seperti } \\
\text { cat, buku, kertas dan krayon. }\end{array}$ \\
\hline $\begin{array}{l}\text { Linear repetitive } \\
\text { stage }\end{array}$ & 2 & $\begin{array}{l}\text { Orangtua dan guru memberi kegiatan yang berkaitan } \\
\text { dengan tulisan, misalnya bermain peran di restoran, } \\
\text { dimana seorang pramusaji menuliskan menu yang akan } \\
\text { dipesan oleh pelanggan, atau seorang dokter yang akan } \\
\text { menulis resep obat. }\end{array}$ \\
\hline $\begin{array}{l}\text { Random letter } \\
\text { stage }\end{array}$ & 3 & $\begin{array}{l}\text { Orang tua memberikan kegiatan supaya anak dapat } \\
\text { menuangkan ide pada gambar menjadi tulisan walaupun } \\
\text { kata yang muncul tidak utuh (hurufnya acak), contoh: } \\
\text { anak ingin menulis kata "aku pergi ke taman safari" } \\
\text { tetapi yang muncul "aku pgi k tmn sfri". }\end{array}$ \\
\hline $\begin{array}{l}\text { Letter name writing } \\
\text { or phonetic writing } \\
\text { stage }\end{array}$ & 4 & $\begin{array}{l}\text { Orang tua dan guru memotivasi anak agar sering latihan } \\
\text { untuk menulis terutama sesuai dengan apa yang ia } \\
\text { dengar. }\end{array}$ \\
\hline
\end{tabular}

HASIL DAN PEMBAHASAN

Tabel 1. Hasil karya Tahapan Menulis Siswa Kelompok B-1 berjumlah 15 anak

\begin{tabular}{|l|l|l|l|l|l|l|l|}
\hline No & Nama & \multicolumn{3}{|c|}{ Tahapan Perkembangan Menulis } & Penilaia \\
Anak & & $\begin{array}{c}\text { Minggu } \\
\text { ke-1 }\end{array}$ & $\begin{array}{c}\text { Minggu } \\
\text { ke-2 }\end{array}$ & $\begin{array}{c}\text { Minggu } \\
\text { ke-3 }\end{array}$ & $\begin{array}{c}\text { Minggu } \\
\text { ke-4 }\end{array}$ & $\begin{array}{c}\text { Penilaian } \\
\text { Skor }\end{array}$ \\
\hline 1. & Fian & Tahap 2 & Tahap 2 & Tahap 3 & Tahap 2 & 2 & Cukup \\
\hline 2. & Azizah & Tahap 2 & Tahap 3 & Tahap 3 & Tahap 2 & 3 & Baik \\
\hline 3. & Annisa & Tahap 2 & Tahap 3 & Tahap 4 & Tahap 3 & 3 & Baik \\
\hline 4. & Alma & Tahap 3 & Tahap 4 & Tahap 4 & Tahap 3 & 4 & Sangat baik \\
\hline 5. & Dimas & Tahap 2 & Tahap 3 & Tahap 2 & Tahap 2 & 2 & Cukup \\
\hline 6. & Inu & Tahap 1 & Tahap 2 & Tahap 2 & Tahap 3 & 2 & Cukup \\
\hline 7. & Fadly & Tahap 1 & Tahap 2 & Tahap 3 & Tahap 2 & 2 & Cukup \\
\hline 8. & Fajar & Tahap 3 & Tahap 2 & Tahap 2 & Tahap 3 & 3 & Baik \\
\hline 9. & Juan & Tahap 2 & Tahap 2 & Tahap 2 & Tahap 2 & 2 & Cukup \\
\hline 10. & Rifa & Tahap 1 & Tahap 1 & Tahap 2 & Tahap 1 & 1 & Kurang \\
\hline 11. & Nizam & Tahap 1 & Tahap 1 & Tahap 2 & Tahap 1 & 1 & Kurang \\
\hline 12. & Nur & Tahap 2 & Tahap 1 & Tahap 2 & Tahap 1 & 2 & Cukup \\
\hline 13 & Syifa & Tahap 2 & Tahap 1 & Tahap 2 & Tahap 2 & 2 & Cukup \\
\hline 14. & Adli & Tahap 1 & Tahap 2 & Tahap 3 & Tahap 3 & 3 & Baik \\
\hline 15. & Inu & Tahap 3 & Tahap 2 & Tahap 2 & Tahap 2 & 2 & Cukup \\
\hline
\end{tabular}


Hasil analisis dari penelitian Tahap Perkembangan Menulis pada Anak Kelompok B TK Islam Assaadahberjumlah 15 anak selama 1 bulan berdasarkan dari rata-rata hasil karya tulisan anak pada Tabel diatas adalah sebagai berikut:

Tabel 4. Rekapitulasi Tahap Perkembangan Menulis Anak

\begin{tabular}{|l|l|l|l|l|}
\hline \multicolumn{1}{|c|}{ Skor Penilaian } & \multicolumn{1}{c|}{ Minggu ke-1 } & Minggu ke-2 & Minggu ke-3 & Minggu ke-4 \\
\hline Kurang & 5 & 4 & - & 3 \\
\hline Cukup & 7 & 7 & 9 & 7 \\
\hline Baik & 3 & 3 & 4 & 5 \\
\hline Sangat baik & - & 1 & 2 & - \\
\hline Jumlah & 15 & 15 & 15 & 15 \\
\hline
\end{tabular}

Hasil analisis dari penelitian Tahap Perkembangan Menulis pada Anak Kelompok B TK Islam Assaadah berjumlah 15 anak selama 1 bulan berdasarkan dari rata-rata hasil karya tulisan anak dan selanjutnya dihitung dengan Diagram Lingkaran diatas adalah sebagai berikut:

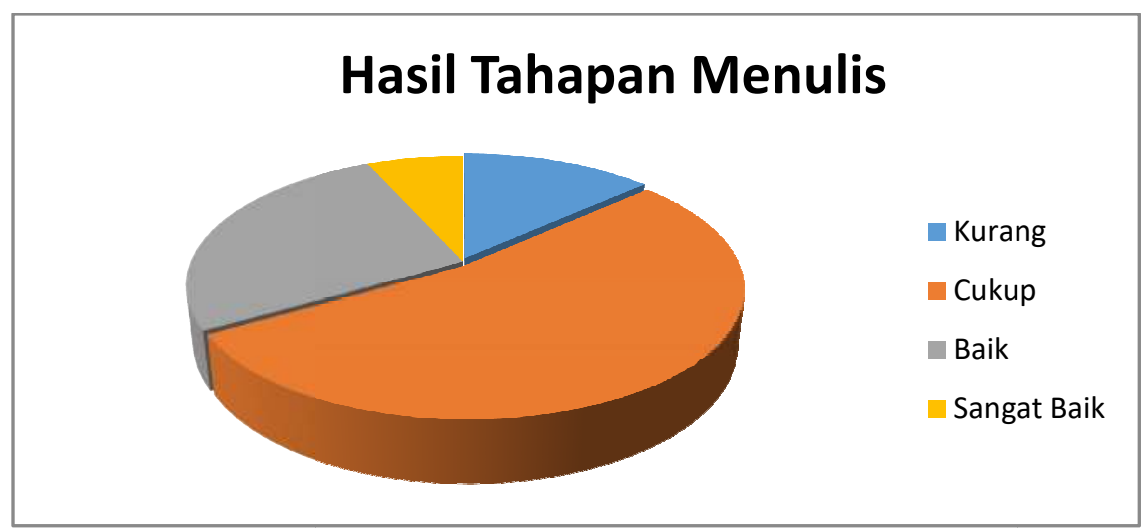

1. Jumlah anak pada perkembangan menulis tahap 1 yaitu 2 anak artinya pada tahap ini anak masih kurang optimal perkembangan menulisnya. Stimulus yang diberikan adalah Orang tua dan guru pada tahap mencoret dapat menjadi model dan menyediakan bahan untuk menulis seperti cat, buku, kertas dan krayon

2. Jumlah anak pada perkembangan menulis tahap 2 yaitu 2 anak artinya pada tahap ini anak masih cukup optimal perkembangan menulisnya.Orangtua dan guru memberi kegiatan yang berkaitan dengan tulisan, misalnya bermain peran di restoran, dimana seorang 
pramusaji menuliskan menu yang akan dipesan oleh pelanggan, atau seorang dokter yang akan menulis resep obat.

3. Jumlah anak pada perkembangan menulis tahap 3 yaitu 2 anak artinya pada tahap ini anak berkembang dengan baik.Stimulasi yang diberikan pada anak adalah orang tua memberikan kegiatan supaya anak dapat menuangkan ide pada gambar menjadi tulisan walaupun kata yang muncul tidak utuh (hurufnya acak), contoh: anak ingin menulis kata " aku pergi ke taman safari” tetapi yang muncul "aku pgi k tmn sfri”.

4. Jumlah anak pada perkembangan menulis tahap 4 yaitu 2 anak artinya pada tahap ini anak sangat baik optimal perkembangan menulisnya.Stimulasi yang diberikan kepada anak adalah orang tua dan guru memotivasi anak agar sering latihan untuk menulis terutama sesuai dengan apa yang ia dengar

\section{SIMPULAN}

Simpulan dari hasil penelitian yang berfokus pada tahap perkembangan menulis anak murid kelompok B-1 di TK Islam Assaadah Limo Depok adalah sebagai berikut:

1. Para guru di TK pada umumnya dan guru TK Assaadah pada khususnya dapat menganalisis pada tahapan menulis keberapa peserta didiknya dengan cara mengidentifikasi dari lembar kerja tulisan anak.

2. Dengan mengetahui tahapan perkembangan menulis anak, guru diharapkan akan dapat menstimulasi sesuai kebutuhan berdasarkan tahapan tersebut, sehingga perkembangan menulis anak menjadi optimal.

3. Jika anak masih pada tahap yang kurang dalam perkembangan menulisnya, guru akan mampu mendeteksi dini kesulitan yang dialami anak dalam menulis, maka guru akan segera mengatasi agar perkembangan anak didik tidak akan terlambat.

4. Guru harus terus melatih menulis anak didiknya meskipun anak tersebut sudah sampai tahapan menulis sangat baik perkembangannya terutama anak menulis apa saja yang yang ia dengar.

5. Stimulasi yang tepat dari guru pada tahap perkembangan menulis anak, menjadikan anak optimal perkembangan menulisnya. 


\section{DAFTAR PUSTAKA}

A. Alek \& Achmad H.P. (2010). Bahasa Indonesia untik Perguruan Tinggi. Jakarta: Kencana Prenada Media Group

Arikunto, Suharsimi. (2006). Prosedur Penelitian: Suatu Pendektaan Praktek Edisi Revisi. Jakarta: PT. Rineka Cipta

(2006). Prosedur Penelitian: Suatu Pendektaan Praktek Edisi Revisi.

Jakarta: PT. Rineka Cipta

Departemen Pendidikan Nasional.(2014). Kamus Besar Bahasa Indonesia Edisi Keempat. Jakarta: Gramedia Pustaka Utama

Musfiroh, Tadkiroatun. (2008). Menumbuhkembangkan BACA-TULIS ANAK USIA DINI. Jakarta: Gramedia Widiasarana Indonesia

Nurgiyantoro, Burhan. (2012). Statistik Terapan untuk Penelitian Ilmu- ilmu Sosial. Yogyakarta: Gadjah Mada University Press

Pusat Pengembangan Profesi Pendidik BPSDMPK, Kemdibud RI. 2013. Modul Pendidikan dan Latihan Profesi Guru Taman Kanak-kanak. Jakarta: Kemendikbud RI

Suparno \& Muhammad Yunus. 2002. Keterampilan Dasar Menulis. Jakarta: Universitas Terbuka 2007. Keterampilan Dasar Menulis. Jakarta: Universitas

Terbuka

Saddhono Kundharu \& St. Y. Slamet.2014. Pembelajaran Keterampilan Berbahasa Indonesia, Teori dan Aplikasi. Yogyakarta: Graha Ilmu.

Tarigan,HenriGuntur.2008.MenulisSebagaiSuatuKeterampilanBerbahasa.

Bandung: AngkasaBandung. 